\title{
INCORPORATION OF ZINC ATOMS INTO GALLOPHOSPHATE MOLECULAR SIEVE
}

\author{
MICHIHIRO MIYAKE, MASATOSHI YOSHINO AND MOTOHIDE \\ MATSUDA \\ Department of Environmental Chemistry and Materials, Faculty of Environmental \\ Science and Technology, Okayama University, Tsushima-Naka, Okayama \\ 700-8530, Japan
}

\begin{abstract}
Zn-doped gallophosphate molecular sieve with good crystallinity was hydrothermally prepared at $170^{\circ} \mathrm{C}$, and the addition of a small amount of $\mathrm{ZnO}$ to the starting gel was found to promote the crystallization process and crystal growth. The characterization by chemical analysis, X-ray diffraction and molecular dynamic simulation suggested the substitution of $\mathrm{Zn}$ atoms for $\mathrm{Ga}$ atoms in the framework of $\mathrm{Zn}$-doped gallophosphate molecular sieve.
\end{abstract}

\section{INTRODUCTION}

Gallophosphate molecular sieve (denoted as $\mathrm{GaPO}_{4}$ below) with unique structure was derived from the study on isomorphous replacement of aluminophosphate molecular sieve. ${ }^{1)}$ Figure 1 shows framework structure of $\mathrm{GaPO}_{4}$. The framework structure consists of two types of double four-rings, basic structural units, which form $\alpha$-cages, rpa- cages and three-dimensional channel systems, i. e. 8and 20 -memmbered ring channels. The 8 -membered ring channels with a diameter of about 3.8 $\AA$ run through the $\alpha$ - and rpa-cages. The 20 -membered ring channels with a diameter of about $13.2 \AA$ are three-dimensionally surrounded by the 8-membered ring channels, and create the supercage with body diagonal of about 30 $\AA$ at intersections. As the supercage has unusual-shaped windows due to the presence of terminal hydroxyl groups, gallophosphate molecular sieve was named cloverite after the shape of the window, like four-leafed clover.

The incorporations of transition metals into the framework of zeolites and 
aluminophosphate molecular sieves are of great interest in several applications such as shape-selective sorption and catalytic process. Transition metal-substituted $\mathrm{GaPO}_{4}$ is also of interest in similar applications, because of the existence of unique three-dimensional channel systems in the structure. We have investigated the crystallization field of transition metal-doped $\mathrm{GaPO}_{4}{ }^{2}{ }^{2}$ In this paper, we report the preparation of $\mathrm{Zn}$-doped $\mathrm{GaPO}_{4}$ (denoted as $\mathrm{Zn}-\mathrm{GaPO}_{4}$ below), and the characterization of the resulting

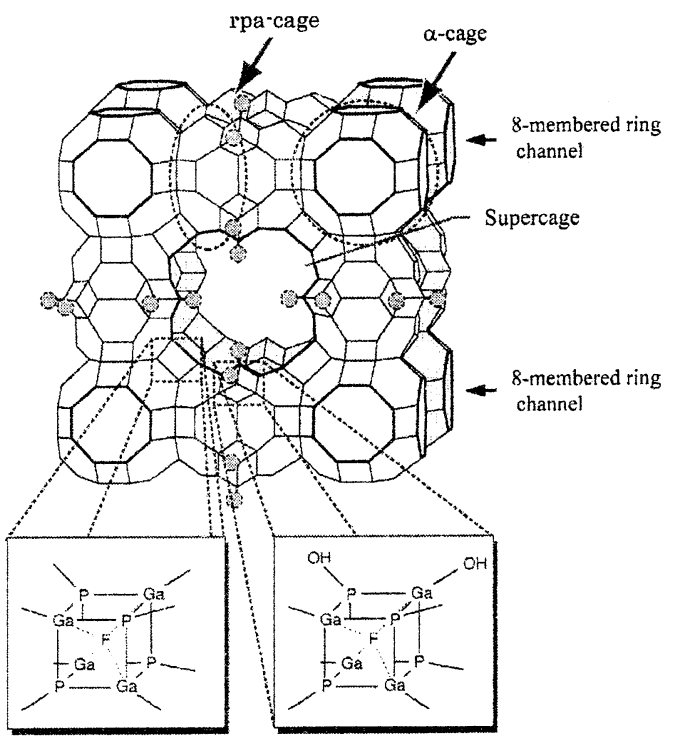

FIGURE 1 Framework structure of $\mathrm{GaPO}_{4}$ compounds by chemical analysis, powder X-ray diffraction (XRD), scanning electron microscopy (SEM), thermal analysis (TG - DTA), and molecular dynamic (MD) simulation.

\section{EXPERIMENTAL}

$\mathrm{GaPO}_{4}$ and $\mathrm{Zn}-\mathrm{GaPO}_{4}$ were hydrothermally synthesized from the starting gels with compositions; $\mathrm{Ga}_{2} \mathrm{O}_{3} \cdot x \mathrm{ZnO} \cdot \mathrm{P}_{2} \mathrm{O}_{5} \cdot \mathrm{HF} \cdot 6$ quinuclidine $\cdot 130 \mathrm{H}_{2} \mathrm{O}(0 \leq \mathrm{x} \leq 0.22)$, referring to previous reports. ${ }^{3,4)} \mathrm{Ga}_{2}\left(\mathrm{SO}_{4}\right)_{3}$ (Aldrich, special grade) and $\mathrm{ZnSO}_{4} \cdot 7 \mathrm{H}_{2} \mathrm{O}$ (Kanto, special grade) were dissolved in distilled water, and $\mathrm{H}_{3} \mathrm{PO}_{4}$ (Wako, 85\%) was added to the solution with stirring. Then, HF (Wako, 47\%) and quinuclidine (Aldrich, special grade) as a template were finally added to the mixture, and the mixed gel was, moreover, stirred to obtain the homogenization. The gel was loaded into a Teflon-lined autoclave, and allowed to react at $170{ }^{\circ} \mathrm{C}$ for $0.25-24 \mathrm{~h}$. After the hydrothermal treatment, the products were filtered, washed repeatedly with deionized water, and dried at $60^{\circ} \mathrm{C}$.

The resulting materials were examined by XRD, using a Rigaku RINT2000 diffractometer with monochromated $\mathrm{CuK} \alpha$ radiation. The morphologies of the resulting crystals were characterized by SEM, using a JEOL JSM-6300 instrument. TG-DTA was carried out with heating rate of $10{ }^{\circ} \mathrm{C} / \mathrm{min}$ up to $1000{ }^{\circ} \mathrm{C}$, using a Rigaku TAS-100 instrument. The chemical compositions were analyzed by 
electron-probe microanalyzer (EPMA), using a JEOL JXA-733 instrument. The MD simulations were performed, using Cerius2 software (Molecular Simulations Inc.) on a SGI ONIX2 computer.

\section{RESULTS AND DISCUSSION}

XRD patterns of the resulting specimens are shown as a function of $\mathrm{x}, \mathrm{ZnO} / \mathrm{Ga}_{2} \mathrm{O}_{3}$ ratio, in the starting gel in Figure 2. All specimens were basically identified as a $\mathrm{GaPO}_{4}$-type with cubic structure. The crystallinity of $\mathrm{Zn}-\mathrm{GaPO}_{4}$ increased, especially the XRD intensity peak at around $2 \theta=3.5^{\circ}$ increased with increasing $\mathrm{ZnO}$ $/ \mathrm{Ga}_{2} \mathrm{O}_{3}$ ratio up to $\mathrm{x}=0.14$ in the starting gel. An impurity, however, coexisted with $\mathrm{Zn}-\mathrm{GaPO}_{4}$ in the products obtained from the starting gels with $\mathrm{ZnO} / \mathrm{Ga}_{2} \mathrm{O}_{3}$ ratio greater than $\mathrm{x}=0.14$, and the crystallinity of $\mathrm{Zn}-\mathrm{GaPO}_{4}$ decreased. These mean that the addition of a small amount of $\mathrm{ZnO}$ to the starting gel yields $\mathrm{Zn}-\mathrm{GaPO}_{4}$ with good crystallinity. After that, $\mathrm{Zn}-\mathrm{GaPO}_{4}$ prepared from the

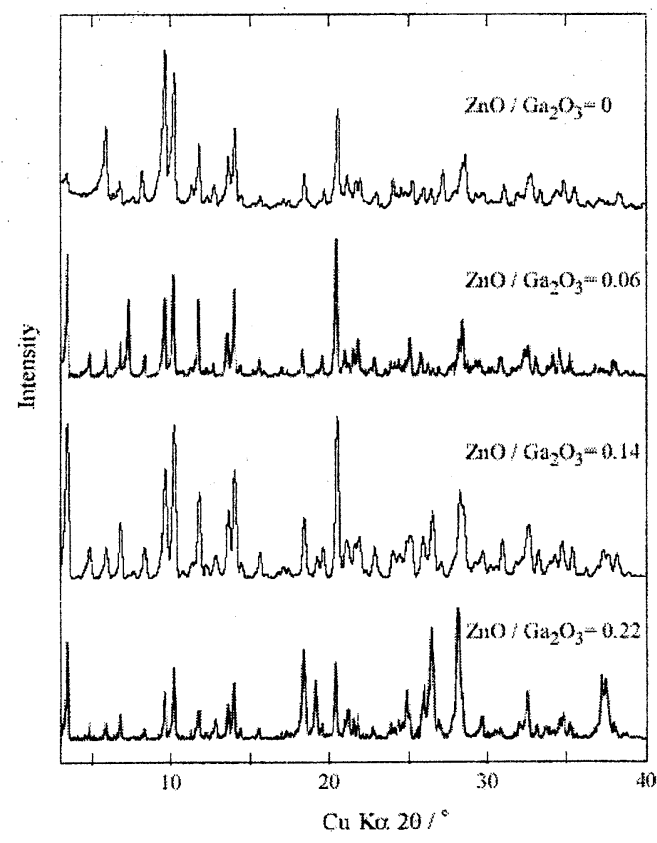

FIGURE 2 XRD patterns of $\mathrm{Zn}-\mathrm{GaPO}_{4}$ as a function of $\mathrm{ZnO} / \mathrm{Ga}_{2} \mathrm{O}_{3}$ ratio in starting gel

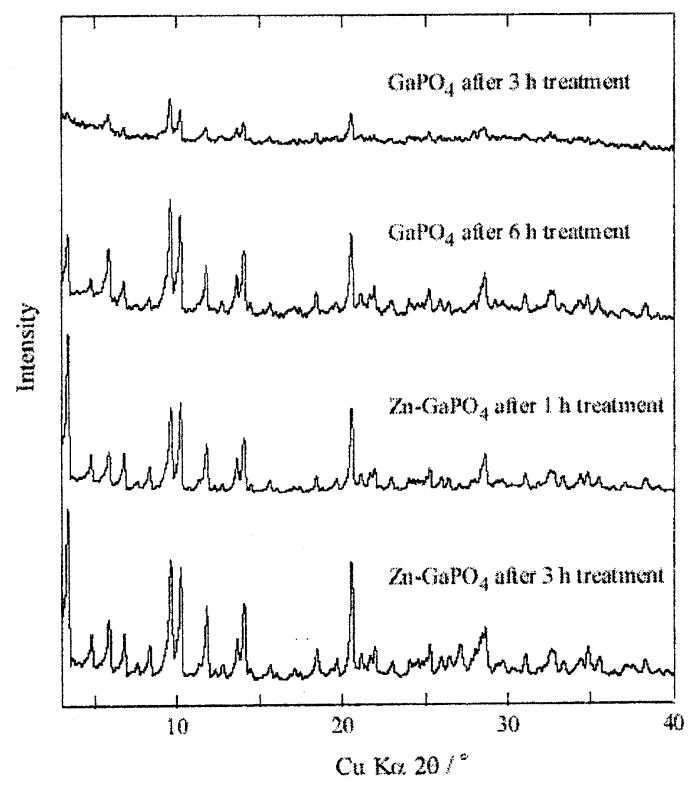

FIGURE 3 XRD patterns of $\mathrm{GaPO}_{4}$ and $\mathrm{Zn}$ $\mathrm{GaPO}_{4}$ as a function of reaction time 
starting gel with $\mathrm{ZnO} / \mathrm{Ga}_{2} \mathrm{O}_{3}=0.14$ was, therefore, employed in the characterization. The unit cell dimensions estimated from the XRD patterns were $a=51.97(3)$ and 52.12(4) $\AA$ for $\mathrm{GaPO}_{4}$ and $\mathrm{Zn}-\mathrm{GaPO}_{4}$, respectively. The unit cell of $\mathrm{Zn}-\mathrm{GaPO}_{4}$ significantly expands, compared with that of $\mathrm{GaPO}_{4}$. This result suggests that $\mathrm{Zn}$ atoms are incorporated into the framework, because the ionic radius of $\mathrm{Zn}^{2+}$ ion is larger than that of $\mathrm{Ga}^{3+}$ ion. ${ }^{5)}$

XRD patterns of $\mathrm{GaPO}_{4}$ and $\mathrm{Zn}-\mathrm{GaPO}_{4}$ are shown as a function of reaction time in Figure 3. The crystallization rates were quite different from each other. Namely, a trace of $\mathrm{GaPO}_{4}$ phase was observed in the product treated for $3 \mathrm{~h}$, and then the XRD intensities of $\mathrm{GaPO}_{4}$ phase gradually increased with elongating reaction time. On the other hand, $\mathrm{Zn}-\mathrm{GaPO}_{4}$ phase already appeared in the product treated for $1 \mathrm{~h}$, and the XRD intensities of $\mathrm{Zn}-\mathrm{GaPO}_{4}$ phase drastically increased in a short reaction time. The crystallization process was found to be accelerated by the addition of $\mathrm{ZnO}$ to the starting gel.

SEM microphotographs of $\mathrm{GaPO}_{4}$ and $\mathrm{Zn}-\mathrm{GaPO}_{4}$ after $24 \mathrm{~h}$ treatment are displayed in Figure 4. The crystals of both specimens were quite different in size, although they exhibited typical morphologies, i. e., truncated cubes. ${ }^{3)} \mathrm{Zn}-\mathrm{GaPO}_{4}$ crystals are extremely large and exhibit a morphology of truncated cubes with edge dimension of about $20 \mu \mathrm{m}$, compared with $\mathrm{GaPO}_{4}$ crystals with edge dimension less than $1 \mu \mathrm{m}$. This result indicates that the addition of $\mathrm{ZnO}$ to the starting gel is effective in promoting the crystal growth.

EPMA showed that atomic ratios estimated were $1.0 \mathrm{Ga}$ : $1.0 \mathrm{P}$ for $\mathrm{GaPO}_{4}$ and $0.1 \mathrm{Zn}$ : $0.9 \mathrm{Ga}: 1.0 \mathrm{P}$ for $\mathrm{Zn}-\mathrm{GaPO}_{4}$, respectively. Namely, it is suggested that about $10 \%$ of $\mathrm{Ga}$ atoms in the framework of $\mathrm{GaPO} 4$ are replaced with $\mathrm{Zn}$ atoms. This suggestion is consistent with the expansion of unit cell in $\mathrm{Zn}-\mathrm{GaPO}_{4}$. Quinuclidine molecules
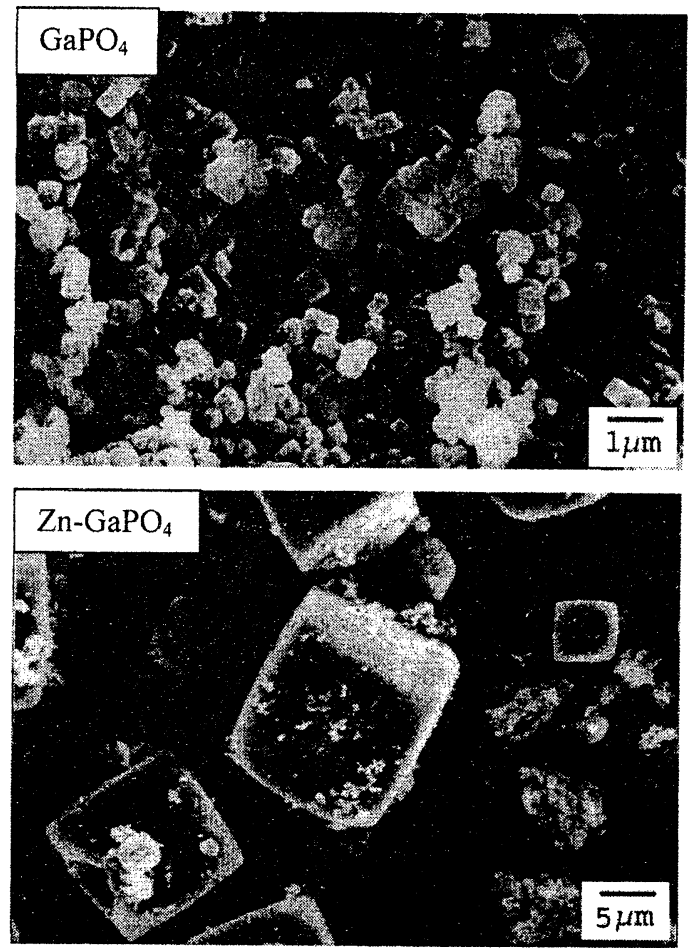

Figure 4 SEM microphotographs of $\mathrm{GaPO}_{4}$ and $\mathrm{Zn}-\mathrm{GaPO}_{4}$ after $24 \mathrm{~h}$ treatment 
encapsulated in the unique channel systems of $\mathrm{GaPO}_{4}$ and $\mathrm{Zn}-\mathrm{GaPO}_{4}$ were estimated to be 135 and 168 per unit cell from TG - DTA, respectively. $\quad \mathrm{GaPO}_{4}$ and $\mathrm{Zn}-\mathrm{GaPO}_{4}$ were collapsed by the heat treatment up to $500{ }^{\circ} \mathrm{C}$, suggesting the presence of quinuclidine was essential to maintain the framework structure.

Next, the MD simulations were performed in order to investigate the locations of $\mathrm{Zn}$ atoms, because it is difficult to experimentally clarify the locations of $\mathrm{Zn}$ atoms by X-ray Rietveld method. The chemical

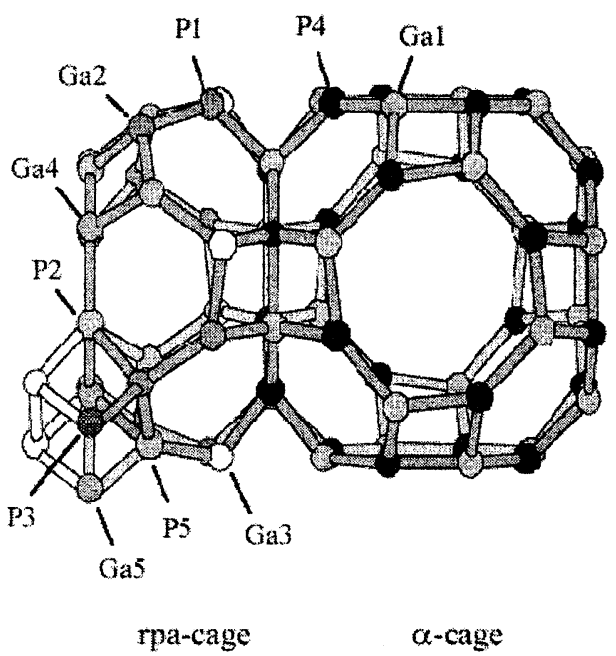

FIGURE 5 Crystallographic framework sites of $\mathrm{GaPO}_{4}$ compositions per unit cell used in the $\mathrm{MD}$ simulation were assumed to be $\mathrm{Ga}_{768} \mathrm{P}_{768} \mathrm{O}_{2976}(\mathrm{OH})_{192} \mathrm{~F}_{135} \mathrm{Q}_{135} \quad$ (Q: quinuclidine) for $\mathrm{GaPO}_{4}$ and $\mathrm{Zn}_{77} \mathrm{Ga}_{691} \mathrm{P}_{768} \mathrm{O}_{2976}(\mathrm{OH})_{192} \mathrm{~F}_{91} \mathrm{Q}_{168}$ for $\mathrm{Zn}-\mathrm{GaPO}_{4}$, respectively, considering the results of chemical analyses and the electrical neutrality of unit cell. The framework structure used in the MD simulations was constructed, referring to the previous report. ${ }^{1)}$ First, the five models $\left(\mathrm{Zn}-\mathrm{GaPO}_{4} 1 \sim 5\right)$, where $\mathrm{Zn}$ atoms individually occupied five crystallographic framework sites for Ga atoms (Ga1 Ga5), as shown in Figure 5, were examined for $\mathrm{Zn}-\mathrm{GaPO}_{4}$ structure. Ga atoms were replaced with $\mathrm{Zn}$ atoms, using a disorder module of Cerius 2 software, and quinuclidine molecules were loaded into the models by Monte Carlo adsorption simulations at synthetic conditions. After the energies of initial models were minimized on the MD simulations, the configurations of templates were examined by fixing the framework atoms. The simulations of 50,000 steps at interval of $1 \mathrm{~ns}$ were carried out at $300 \mathrm{~K}$, using Universal Force Field (UFF) and NTP ensemble.

TABLE 1 Unit cell dimensions and total energies of structural models by MD simulations at $300 \mathrm{~K}$

The resulting total energies and unit cell dimensions of the models on the MD simulations are listed in Table 1. The total energy of $\mathrm{Zn}-\mathrm{GaPO}_{4}$ was anticipated to be much lower than that of

\begin{tabular}{lcc}
\hline Models & $\mathrm{a}(\AA)$ & Total energy $\left(\mathrm{kJ} \mathrm{mol}^{-1}\right)$ \\
\hline $\mathrm{GaPO}_{4}$ & 52.71 & $3.77 \times 10^{5}$ \\
$\mathrm{Zn}-\mathrm{GaPO}_{4} 1$ & 52.77 & $3.52 \times 10^{5}$ \\
$\mathrm{Zn}-\mathrm{GaPO}_{4} 2$ & 52.77 & $3.56 \times 10^{5}$ \\
$\mathrm{Zn}-\mathrm{GaPO}_{4} 3$ & 52.79 & $3.50 \times 10^{5}$ \\
$\mathrm{Zn}-\mathrm{GaPO}_{4} 4$ & 52.87 & $3.81 \times 10^{5}$ \\
$\mathrm{Zn}-\mathrm{GaPO}_{4} 5$ & 52.76 & $3.71 \times 10^{5}$ \\
$\mathrm{Zn}-\mathrm{GaPO}_{4} 6$ & 52.84 & $3.48 \times 10^{5}$ \\
$\mathrm{Zn}-\mathrm{GaPO}_{4} 7$ & 52.83 & $3.58 \times 10^{5}$ \\
\hline
\end{tabular}


$\mathrm{GaPO}_{4}$, since the doping $\mathrm{Zn}$ atoms promote the crystallization process. Although the total energy of $\mathrm{Zn}-\mathrm{GaPO}_{4} 3$ model was lowest, the unit cell dimension hardly expanded. Accordingly, new models were made by locating $\mathrm{Zn}$ atoms evenly at $\mathrm{Gal}$ and 3 sites for $\mathrm{Zn}-\mathrm{GaPO}_{4} 6$, and by locating $\mathrm{Zn}$ atoms evenly at $\mathrm{Ga1}, 2$ and 3 sites for $\mathrm{Zn}-\mathrm{GaPO}_{4} 7$, respectively, considering the total energies of $\mathrm{Zn}-\mathrm{GaPO}_{4} 1 \sim 3$ models were lower than that of $\mathrm{GaPO}_{4}$ model. The MD simulation of $\mathrm{Zn}-\mathrm{GaPO}_{4} 6$ model resulted in a larger unit cell expansion and a lower total energy than that of $\mathrm{Zn}-\mathrm{GaPO}_{4} 3$ model, whereas the MD simulation of $\mathrm{Zn}-\mathrm{GaPO}_{4} 7$ model resulted in a larger unit cell expansion and a higher total energy than that of $\mathrm{Zn}-\mathrm{GaPO}_{4} 3$ model, as listed in Table 1. Consequently, $\mathrm{Zn}-\mathrm{GaPO}_{4} 6$ model, which indicates that $\mathrm{Zn}$ atoms occupy the sites on $\alpha$-cage and rpa-cage close to $\alpha$-cage, was selected as the most suitable model for $\mathrm{Zn}-\mathrm{GaPO}_{4}$ structure. The $\mathrm{MD}$ simulation of $\mathrm{Zn}-\mathrm{GaPO}_{4} 6$ model also revealed the configurations of quinuclidine molecules in the structure. Namely, quinuclidine molecules were located at every corners of the supercage, in the 8-membered ring channels, and furthermore around the terminal $\mathrm{OH}^{-}$groups in the 20 -membered ring channels.

In conclusion, the addition of $\mathrm{ZnO}$ to the starting gel up to $\mathrm{ZnO} / \mathrm{Ga}_{2} \mathrm{O}_{3}=0.14$ was found to prornote the crystallization process and bring much larger $\mathrm{Zn}-\mathrm{GaPO}_{4}$ crystals than $\mathrm{GaPO}_{4}$. The MD simulation of $\mathrm{Zn}-\mathrm{GaPO}_{4} 6$ model supported the experimental results, i. e. the crystallization process and unit cell expansion, indicating that $\mathrm{Zn}$ atoms were incorporated into the framework of gallophosphate molecular sieve.

\section{$\underline{\text { REFERENCES }}$}

1) M. Estermann, L. B. McCusker, C. Baerlocher, A. Merrouche and H. Kessler, Nature, $\underline{320}, 352$ (1991).

2) M. Yoshino, M. Matsuda and M. Miyake, Solid State Ionics (in press)

3) A. Merrouche, J. Patarin, H. Kessler, M. Souland, L. Delmotte, J. L. Guth and J. F. Joly, Zeolites, 12, 226 (1992).

4) S. M. Bradley, R. F. Howe and J. V. Hanna, Solid State Nucl. Magn. Reson., 2, 37 (1993).

5) R. D. Shannon, Acta Crystallogr., A32, 751 (1976). 